\title{
Atmospheric conditions governing anomalies of the summer and winter cloudiness in Spitsbergen
}

\author{
Ewa Bednorz • Dominika Kaczmarek • \\ Przemyslaw Dudlik
}

Received: 27 November 2013 / Accepted: 4 December 2014 / Published online: 19 December 2014

(C) The Author(s) 2014. This article is published with open access at Springerlink.com

\begin{abstract}
The study is based on data concerning cloudiness for the years 1981-2010 from Svalbard Lufthavn. Atmospheric circulation was characterized using a catalogue of circulation types developed by Niedźwiedź (2013) and average daily values of atmospheric pressure. Intensive cyclogenesis taking place over the north Atlantic expressed by lower-than-normal sea level pressure (SLP), particularly over the Fram Strait and over the east coast of Greenland, enhances the meridional air transport from the southern sector which conveys positive anomalies of cloudiness, namely a very cloudy weather. Negative anomalies of cloudiness over Svalbard Lufthavn occur in the winter when the north Atlantic cyclone path is shifted to the south and goes along the northern Norwegian shore towards the south Barents Sea. In summer, the influence of pressure patterns on cloudiness is weaker than in winter and different circulation patterns induce negative extremes of cloudiness. In the warm season, sunny weather occurs when a distinct anticyclone spreads over the Svalbard Archipelago and to its west, over the Fram Strait and the northern outskirts of the Greenland Sea. Extremely cloudy weather occurs in summer when a weak anticyclone spreads over the Barents Sea, the Novaya Zemlya archipelago and the Kara Sea, while slightly lower-than-normal pressure is observed over Greenland. Such a pressure pattern enhances southerly and south-westerly flow of air masses, bringing humid air. The results obtained in this study demonstrate that cloudiness over Spitsbergen is strongly controlled by the air circulation arising from pressure patterns.
\end{abstract}

Electronic supplementary material The online version of this article (doi:10.1007/s00704-014-1326-5) contains supplementary material, which is available to authorized users.

E. Bednorz $(\triangle) \cdot$ D. Kaczmarek $\cdot$ P. Dudlik

Department of Climatology, Institute of Physical Geography and

Environmental Planning, Adam Mickiewicz University,

Poznań, Poland

e-mail: ewabedno@amu.edu.pl

\section{Introduction}

Research into global climate change shows that the Arctic is particularly susceptible to its effects (IPCC 2007). The warming observed in Arctic areas leads to a decrease in the surface area of glaciers and associated changes in the radiation balance, which is of key importance for shaping the climate. The radiation balance and thus the temperature in higher latitudes are also significantly impacted by cloudiness (Walsh and Chapman 1998; Curry et al. 1996; Vavrus et al. 2011). The influence of cloudiness on the surface temperature is a complex issue. In general, clouds (particularly low-level) are considered to have a global-scale cooling effect (Ramanathan et al. 1989). However, in the Arctic, clouds may enhance the cooling of the surface only during the short midsummer period, while in the rest of the year, they have a warming effect (Intrieri et al. 2002; Curry et al. 1996; Wang and Key 2003; Shupe and Intrieri 2004; Vavrus 2004; Vavrus et al. 2011).

The weather and climate of Polar Regions, including Spitsbergen, are shaped under the considerable influence of atmospheric circulation (Niedźwiedź 2001). Large thermal contrasts between ice-covered Greenland and warm Atlantic waters cause an intense cyclonic activity in the Arctic and, consequently, a quick exchange of air masses, originating from the north and from the south. This contributes to a great variation in weather and temperature conditions (Steffensen 1982; Nordli 1990; Serreze et al. 1993; Førland et al. 1997; Zhang et al. 2004; Marsz and Styszyńska 2007). The impact of the atmospheric circulation caused by the pressure patterns on the climate has been described in several studies concerning the Arctic (e.g. Serreze and Barry 1988; Wielbińska and Skrzypczak 1988; Serreze et al. 1993, 2000; Hanssen-Bauer and Forland 1998; Niedźwiedź 2003, 2006; Zhang et al. 2004; Rogers et al. 2005; Maciejowski and Michniewski 2007; Bednorz 2011; Bednorz and 
Kolendowicz 2013). There are a few studies concerning the impact of the atmospheric circulation on Arctic cloudiness (Kotarba and Widawski 2008; Vavrus et al. 2011). More numerous studies emphasize the role of sea ice reduction and increase of sea surface temperature (SST) on the amount of clouds in the Arctic, mainly due to the enhanced evaporation and impact of increasing SST on static stability (Crane and Barry 1984; Schweiger et al. 1999; Stephens 2005; Schweiger et al. 2008; Kay and Gettelman 2009; Vavrus et al. 2009; Eastman and Warren 2010; Palm et al. 2009; Andrews et al. 2012; Andrews and Ringer 2014).

The aim of this study is to emphasize the influence of atmospheric circulation and the long-distance moisture transport on cloudiness over Spitsbergen, mainly by analysing the atmospheric conditions causing the occurrence of cloudiness extremes.

\section{Area, data and methods}

\subsection{Area of the study}

Spitsbergen together with three large islands Nordaustlandet, Edge Island and Barents Island comprise the Svalbard Archipelago. The name 'Svalbard' also covers the administrative unit of the Kingdom of Norway, which includes Bjornoya (Bear Island) and Hopen (Marsz and Styszyńska 2007). The archipelago is located in the north-western part of the Barents Sea. Spitsbergen is the largest island, in the east bordering on the waters of the Barents Sea, in the north on the Arctic Sea and in the west on the open waters of the Greenland Sea. The Fram Strait divides Spitsbergen from Greenland.

The western coast of Spitsbergen is washed by a warm sea current (the West Spitsbergen Current), which is an arm of the Gulf Stream and flows northwards, along the western coast of Spitsbergen (Piechura et al. 2001). The eastern part of the island is washed by the cold East Spitsbergen Current. Thanks to the activity of the West Spitsbergen Current, waters along the island's western coast are free of ice for the majority of the Arctic summer. These are the most northwards sea areas free of ice cover (Haugan 1999). The western part of the island is warmer, while the interior of Spitsbergen has a more continental climate. The climate of the eastern and northern parts of Spitsbergen is directly impacted by Arctic air masses.

Spitsbergen is located near two stationary baric centres the Icelandic Low and the Greenland High, which determine the movement of air masses over the island and the occurrence of specific types of weather. For the climatic conditions of Spitsbergen, the most important is the Icelandic Low and its long-term fluctuations and also the Arctic front occurring in the vicinity of the island (Markin 1975). Masses of cold Arctic air coming from the north clash with the humid and warm masses of air inflowing from the south. This situation results in heightened cyclonic activity and the high frequency of lows with atmospheric fronts (Serreze and Barry 1988; Serreze et al. 1993; Zhang et al. 2004).

\subsection{Data}

The study is based on data concerning cloudiness for the years 1981-2010 from the Svalbard Lufthavn station $\left(78^{\circ} 15^{\prime} \mathrm{N}\right.$, $15^{\circ} 28^{\prime}$ E) (Fig. 1). Source materials include average daily cloudiness (in octants) obtained from the website eKlima.met.no, administered by the Norwegian Meteorological Institute in Oslo. The Svalbard Lufthavn meteorological station is located in the central part of the island on the banks of a fiord that cuts deeply inland from the west, and for this reason, the local climate has certain continental features. The station is situated near the airport in Longyearbyen at an altitude of $28 \mathrm{~m}$ above sea level, on a coastal terrace at the mouth of the Advent valley and fiord, which opens out northwards, towards the Isfjord running along the line W-E. Masses of air flowing towards the Isfjord from the Greenland Sea directly influence the weather conditions of Svalbard Lufthavn.

Atmospheric circulation was characterized using a catalogue of circulation types developed by Niedźwiedź (2013). In this classification, 21 types of synoptic situations (circulation types) were distinguished on the basis of synoptic maps of Europe, taking into account the direction of air masses advection (N, NE, E, SE, S, SW, W NW, N) and the kind of pressure pattern (a anticyclonic, c cyclonic: $\mathrm{Nc}, \mathrm{Na}, \mathrm{NEc}, \mathrm{NEa}$, etc.). Additionally, four other circulation types were determined: $\mathrm{Ca}$ central anticyclone situation (high centre); Ka anticyclonic wedge or ridge of high pressure; $\mathrm{Cc}$ central cyclonic, centre of low; $\mathrm{Bc}$ trough of low pressure (different directions of air flow and frontal system in the axis of through) and $\mathrm{x}$ unclassified situations or pressure col (Niedźwiedź 2013). Use was also made of average daily values of atmospheric sea level pressure (SLP) and air temperature at the isobaric level of $850 \mathrm{hPa}(\mathrm{T} 850)$ for the area $60-90^{\circ} \mathrm{N}$ and $60^{\circ} \mathrm{W}-80^{\circ} \mathrm{E}$ (Fig. 1), obtained from the National Centre for Environmental Prediction/National Center for Atmospheric Research Reanalysis (NCEP/NCAR) (Kalnay et al. 1996). All the above-mentioned reanalysis data are grid-based (resolution of $2.5 \times 2.5^{\circ}$ ) and they are available in the files of the Climate Research Unit (CRU).

\subsection{Methods}

Values of the average daily degree of cloudiness were converted from the octant scale to a percentage scale and then used to calculate the following basic statistics: monthly averages and long-term averages, standard deviation and the linear trend of long-term changes in the degree of cloudiness. Subsequently, days with positive and negative extremes of cloudiness were determined. 


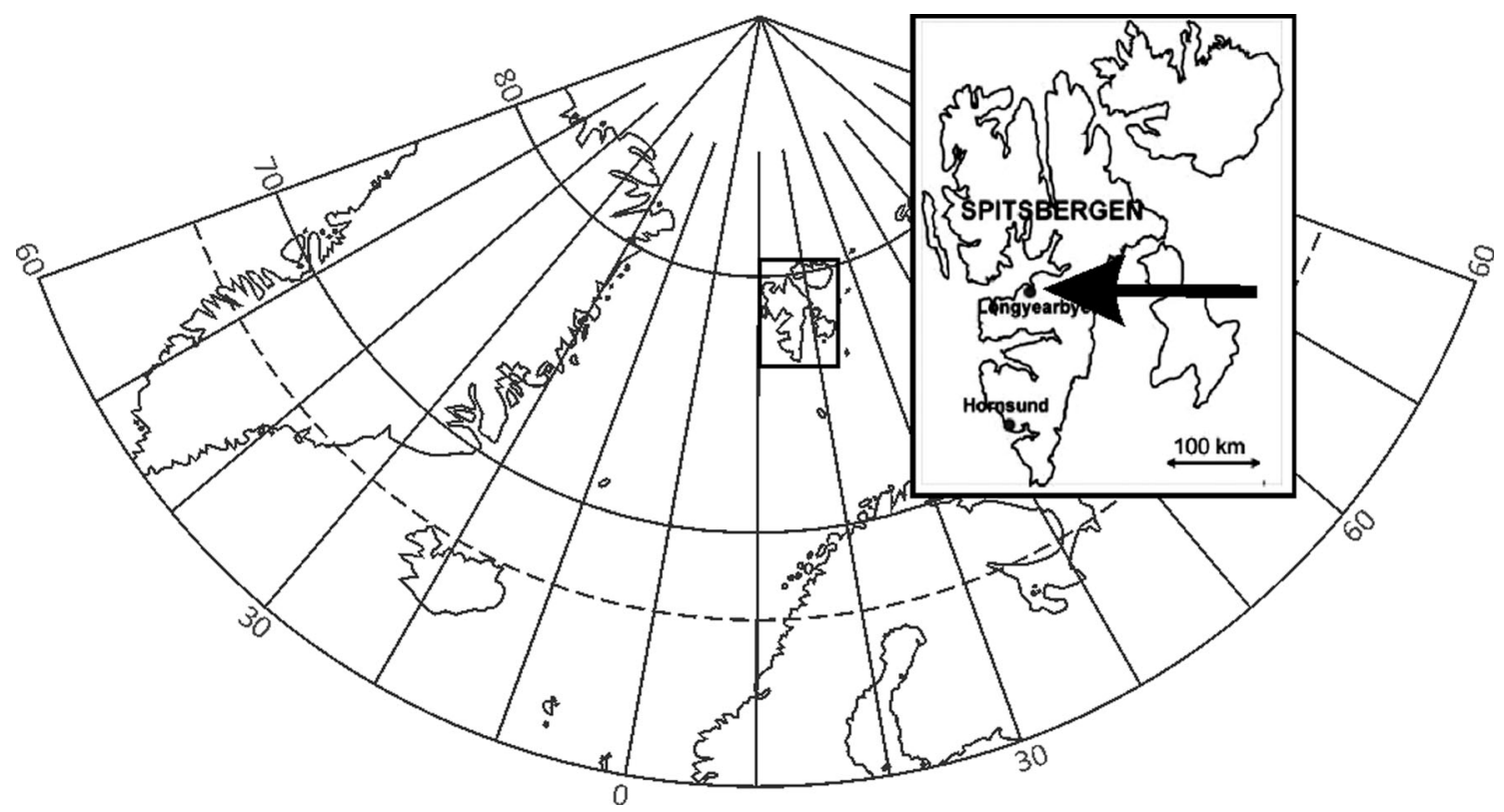

Fig. 1 Area under the study. Location of the Svalbard Lufthavn station indicated with an arrow (Bednorz 2011)

Use was made of the criterion recommended in the IPCC Report (2007), which is based on probability characteristics. An 'extreme phenomenon' is defined as a phenomenon that is rare in terms of statistical distribution; it should occur with a frequency not greater than $10 \%$ (IPCC Report 2007). Days were selected from the entire 30-year period 1981-2010 in which the magnitude of cloudiness was less than or equal to the 10th percentile (clear-sky-weather anomalies) and in which the magnitude of cloudiness was greater than or equal to the 90th percentile (cloudy-weather anomalies) (Żmudzka 2007).

In the next stage of research, atmospheric circulation was characterized for days with extreme cloudiness. To this end, the 'environment to circulation' approach was applied, which means that the circulation classification was carried out along specific environment-based criteria set for a particular environmental phenomenon, i.e. extremes of cloudiness in this case (Yarnal 1993; Yarnal et al. 2001; Dayan et al. 2012). Due to the fact that baric and circulation conditions are different in the summer and winter, the analysis was conducted separately for both seasons. The summer and winter were distinguished on the basis of the average monthly air temperature at Svalbard Lufthavn, assuming average monthly temperatures of 0 and $-10{ }^{\circ} \mathrm{C}$ as threshold values. According to this method, the summer is the period from June to September, with an average monthly temperature of $>0{ }^{\circ} \mathrm{C}$, while the winter lasts from December to March, with an average monthly temperature of $<-10{ }^{\circ} \mathrm{C}$.

In order to relate the occurrence of cloudiness extremes to general synoptic conditions, the circulation types according to Niedźwiedź (2013), conducive to positive/negative cloudiness extremes, were distinguished.
In order to describe the influence of pressure patterns on cloudiness in general, the correlation coefficients between the daily mean cloudiness at Svalbard Lufthavn and the daily values of SLP in the grid points were calculated and mapped separately for the winter and summer seasons. The significance of correlation coefficients was tested using the Fisher $Z$ transformation, which is often applied in cases of spatial correlation (Wilks 1995). Furthermore, composite maps of the SLP means for the days with positive and negative extremes of cloudiness were constructed, separately for winter and summer. In order to find out, whether the composites maps are significantly different from the mean maps, the SLP values from both groups were compared. The comparison was conducted for each grid point separately, using the $t$ test.

Then, anomalies of SLP were computed in each grid point as a difference between mean SLP summer/winter values for the days with positive extremes and mean SLP summer/winter values for the whole period. In order to show broader synoptic conditions of the occurrence of extreme cloudiness, T850 anomalies for the same situations were computed and mapped. Similar maps of SLP and T850 were constructed for the days with negative extremes of cloudiness.

\section{Results}

3.1 Basic characteristics of cloudiness

Average annual total sky cloudiness at the Svalbard Lufthavn station during the period 1981-2010 amounted to $66.6 \%$. 
Greater cloudiness is observed in the summer and early autumn $(75.6 \%)$, with a maximum in September $(77.1 \%)$. The lowest value of cloudiness was observed in the season from December (58.9 \%) to April (59.8 \%) (Fig. 2).

Average annual sky cloudiness is characterized by low variability from year to year (standard deviation $3.1 \%$ ), and no statistically significant trend of change in this parameter was observed during the analysed 30-year period (Fig. 3). The most cloudy year was 1984, with an average cloudiness of $74.2 \%$, while the least cloudy year was $1993(61.74 \%)$. Over the period 1981-2010, a statistically significant increase in the average degree of cloudiness was observed in the winter, with a decrease in the summer (not significant). This corresponds to findings of others concerning cloudiness in the Arctic (Przybylak 1999; Eastman and Warren 2010) and is possibly associated with increasing surface temperatures and decreasing sea ice.

Subsequently, days with extremely low cloudiness were determined for the Svalbard Lufthavn station on the basis of the value of the 10 th percentile, which equals to $\leq 21.25 \%$ of mean daily cloudiness. Values lower than $21.25 \%$ meant negative extremes of cloudiness (clear-sky-weather anomalies, according to Żmudzka 2007). Congruently, days with extremely high cloudiness were determined on the basis of the value of the 90 th percentile which equals to $96.25 \%$. Days with mean cloudiness higher than $96.25 \%$. were considered as days with positive anomalies of cloudiness (cloudy-weather anomalies, according to Żmudzka 2007).

In winter, a considerably greater number of negative anomalies of cloudiness were observed than in summer. During the 4-month-long (December-March) winter period, there are on average 23 days with fine weather (in total 702 instances over 30 years), while in summer (June-September), there are on average 5 days with average daily cloudiness $\leq 21.25 \%$ (in total 156 days). Positive extremes of cloudiness occur on average 16 times in the winter season (in total 481 days over the researched 30-year period) and 18 times in the summer (in total 453 days).

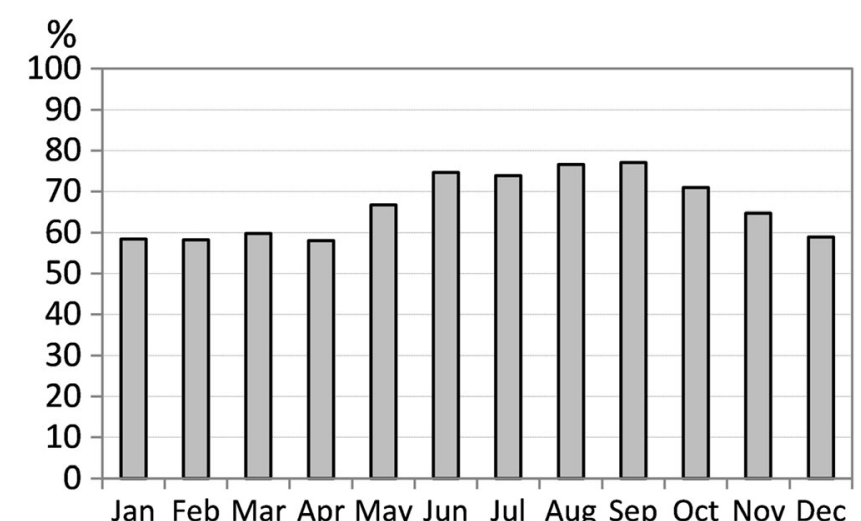

Fig. 2 Annual course of average cloudiness at the Svalbard Lufthavn station in the period 1981-2010

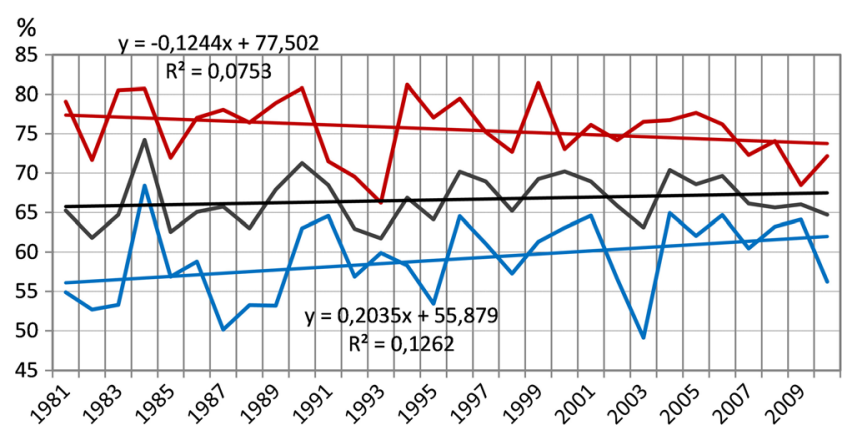

Fig. 3 Multiannual course of mean cloudiness in summer (red line), in winter (blue line) and annually (black) at Svalbard Lufthavn with trend lines and equations for summer (up) and for winter (down)

\subsection{Atmospheric circulation versus anomalies of cloudiness}

Because of its location in the area of the Arctic front, Spitsbergen is characterized by considerable cyclonic activity (approximately $59 \%$ of days in the year, according to the Niedźwiedź's calendar of circulation types for Spitsbergensee chapter 2.2). Cyclone activity is most intense in particular regions of the Arctic, namely near Iceland, between Svalbard and Scandinavia and over Norwegian seas (Serreze et al. 1993; Mc Cabe et al. 2001; Zhang et al. 2004; Rogers et al. 2005). Anticyclonic situations occur over $37 \%$ of days in the year. Indeterminate situations and through of low pressure occur in just under $3.5 \%$ days in the year. Cyclonic situations are more frequent in the winter (nearly $70 \%$ of days) and less frequent in the summer (55\% of days). Anticyclonic situations occur in the winter with a frequency of approximately $29 \%$, and in the summer with a frequency of nearly $42 \%$.

According to Niedźwiedź's calendar of circulation types for Spitsbergen, during the winter season, the inflow of air masses over Spitsbergen occurs most frequently from the east (a frequency of approximately $23 \%$ ), the north-east (17\%) and the south-east (12\%); usually, this is connected with cyclonic circulation. Rogers et al. (2005) identified the Fram Strait as a pathway of cyclonic activity trending towards the high Arctic; other storm track leads from the Barents Seaalso identified by Serreze and Barry (1988); in summer, cyclones may enter the Arctic from the east (Laptev Sea and Chukchi Sea).

In the warm season of the year, the baric gradient is smaller than in winter, while the baric field is blurred and less diverse. Quite frequent (approximately $15 \%$ of days) are situations without a clear direction of inflow of air masses (Ka anticyclonic wedge). Using the Niedźwiedź's typing allowed recognizing general circulation conditions, namely airflow directions and pressure patterns (cyclonic, anticyclonic) which are favourable to occurrence of extreme cloudiness in Spitsbergen. On the other hand, the typing allowed recognizing, which circulation types are not associated with a particular extreme. It appeared that in both seasons of the year, anticyclonic circulation types from the north-eastern sector 
(Na, NEa, Ea) bring about clear-sky-weather anomalies. In winter, clear-sky-weather anomalies also accompany eastern and north-eastern cyclonic types (Ec, Nc), while in summer, cloudless weather is frequently observed in the presence of a high pressure ridge without a clear direction of inflow of air masses (Ka). In the winter period, days with fine weather do not occur when air masses flow in from the west, south and south-west and also in the presence of a north-western circulation connected with a cyclonic centre (Fig. 4).

In winter, cloudy anomalies appear in the centre of the low (Cc) or in the presence of a low pressure trough (Bc) and also under cyclonic conditions when air masses flow in from the south-western sector (SWc, Sc, Wc). Similar circulation types accompany the occurrence of cloudy anomalies in the summer, when considerable cloudiness also occurs under type Ka.

Atmospheric circulation has a great impact on moisture transport and, consequently, on cloudiness in the polar climates. In order to describe the general influence of pressure patterns on cloudiness, correlation coefficients between the daily mean cloudiness at Svalbard Lufthavn and the daily values of SLP were computed. This allowed indicating the location of main pressure centres, which govern the rate of cloudiness at Spitsbergen. Correlation coefficients computed for the winter months prove a strong relationship between the two aforementioned variables. In winter, two main 'centres of action' can be indicated (Fig. 5 left). A lower-than-normal pressure along the east coast of Greenland (particularly over the Fram Strait) is related to higher-than-normal cloudiness over the Svalbard Archipelago (correlation coefficient up to -0.37 ). When active cyclogenesis takes place along the northern coast of Greenland, the cyclones traverse just west of Spitsbergen, with meteorological fronts over the archipelago. On the other hand, lower-than-normal pressure over the south Barents Sea and northern Europe is related to lower-thannormal cloudiness over the Svalbard Archipelago (correlation coefficient $>0.3$ ). In summer, the influence of pressure patterns on cloudiness is weaker (Fig. 5 right). Correlation coefficients between the daily mean cloudiness at Svalbard Lufthavn and the daily values of SLP in grid points computed for the summer months are positive over the northern Europe (up to 0.14), and they are negative over the north-western Atlantic (lowest values below -0.25). The significance of correlation coefficients was tested using the Fisher $\mathrm{Z}$ transformation, which is often applied in cases of spatial correlation. Absolute values of correlation coefficients equal to 0.0324 for summer and 0.0325 for winter appeared to be statistically significant. Significant values are low due to a large number of cases ( $n=3660$ for summer and $n=3630$ for winter). The area of lowest values, indicating low pressure systems spreads west to the Svalbard Archipelago.

The pattern of the mean SLP in winter shows two main centres in the Atlantic sector of the Northern Hemisphere (Fig. 6a). One of them is the Greenland High with the pressure of $1020 \mathrm{hPa}$ in the centre, and the other is the Icelandic Low, with the pressure of $998 \mathrm{hPa}$ in the centre, which is located south-west of Iceland. This low spreads to the north-east, forming the secondary centre $(1002 \mathrm{hPa})$ over the north Atlantic, south of the Svalbard Archipelago. There is a big pressure gradient between Greenland and the aforementioned low centres. A smaller pressure gradient is observed towards the north-eastern Europe where the SLP gradually increases.

At a contour map of SLP, constructed for the days with negative extremes of cloudiness in winter (702 days with cloudless or almost cloudless weather), the northern Atlantic low is pushed to the south-east (Fig. 6b). One of the cyclonic centres is located over the Barents Sea, which is a region of negative SLP anomalies ( $-6 \mathrm{hPa}$ ) (Fig. 6d). According to the $t$ test, absolute values of SLP anomalies higher than $1.5 \mathrm{hPa}$ express statistically significant $(p=0.05)$ difference between composites and winter means. Another centre of negative SLP

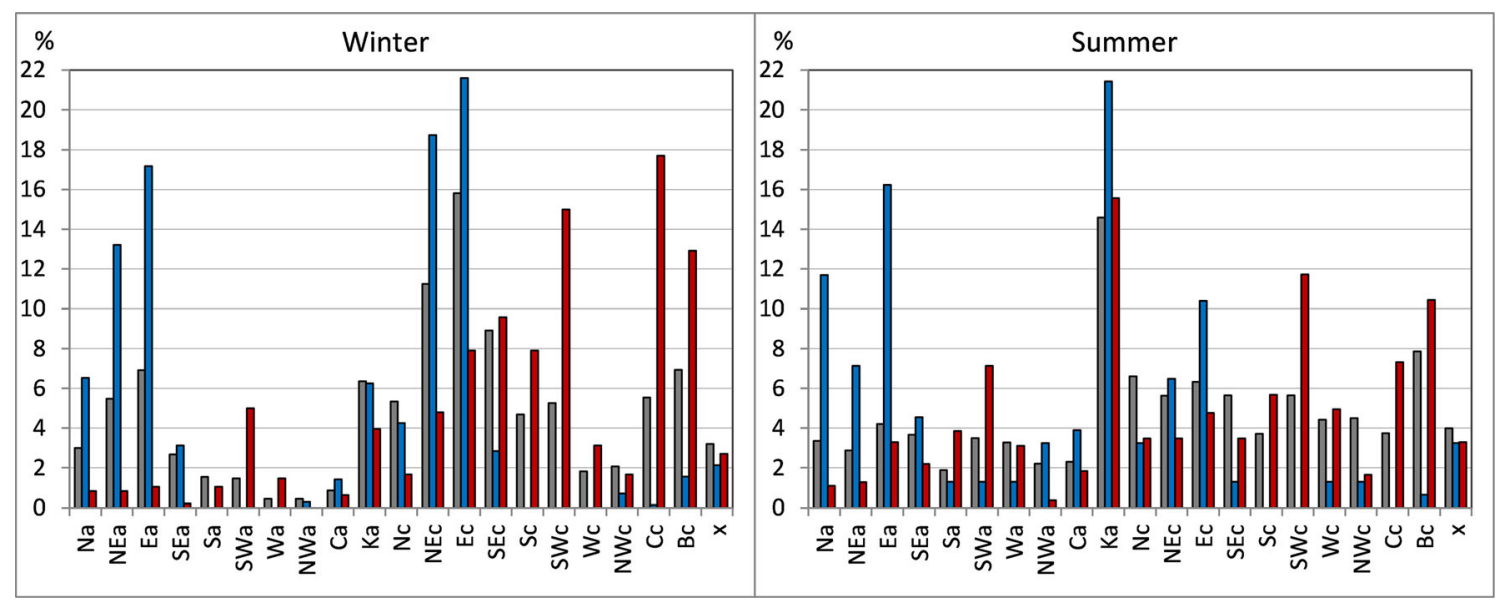

Fig. 4 The frequency of occurrence of circulation types according to Niedźwiedź (2013) ( grey) and the frequency of occurrence of negative extremes of cloudiness (blue) and positive extremes of cloudiness (red) under specific circulation types at Svalbard Lufthavn 


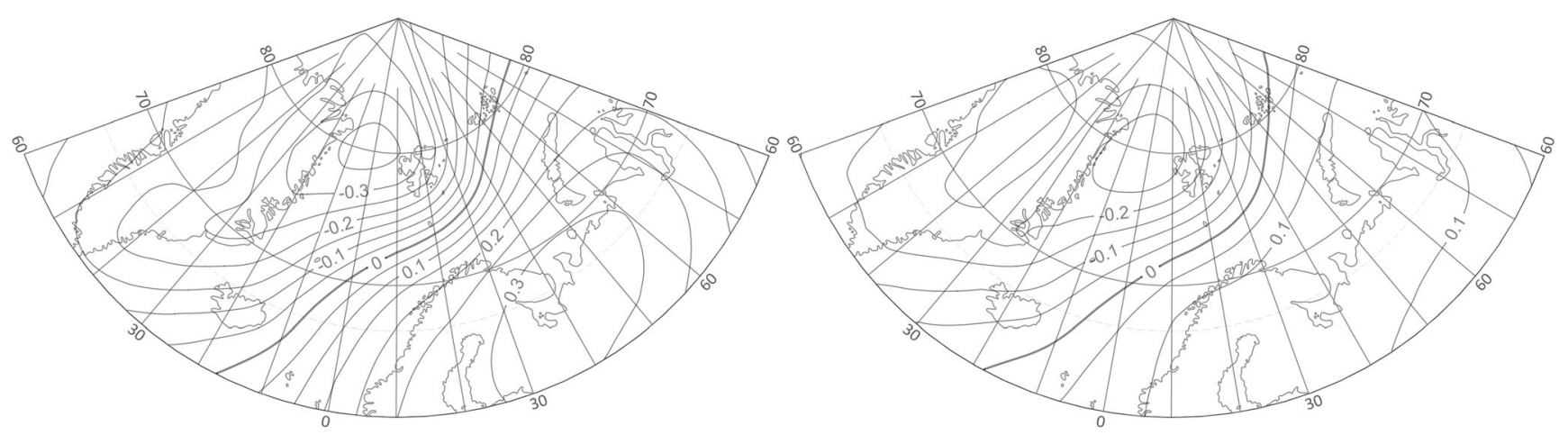

Fig. 5 The field of correlation coefficient between the daily mean cloudiness at Svalbard Lufthavn and daily mean SLP in winter (left) and in summer (right)

anomalies spreads along the northern coast of Norway. Positive SLP anomalies occur over most of the North Atlantic (including the Svalbard Archipelago), over the western part of the Arctic Sea and over Greenland. The centre of positive SLP anomalies is located right over the Fram Strait. Therefore, the Greenland High is stronger than usual while the cyclonic activity over the Fram Strait is much weaker. Such a pressure pattern at the sea level indicates the northern and north-eastern flow, which brings cold Arctic air with low humidity content to the Svalbard Archipelago. Inflow of the cold Arctic air is expressed by negative anomalies of T850 over the entire north Atlantic, exceeding $-3{ }^{\circ} \mathrm{C}$ in the centre over the Svalbard Archipelago (Fig. 6f). According to the $t$ test, absolute values of T 850 anomalies higher than $0.6{ }^{\circ} \mathrm{C}$ are statistically significant at $p=0.05$.

Quite different synoptic situations underlie the positive anomalies of cloudiness, which mean extremely cloudy weather in winter (481 days). The northern Atlantic low is pushed to the north by the high pressure system, located over Europe and expanding to the north-west (Fig. 6c). This is an area of positive SLP anomaly ( $7 \mathrm{hPa}$ ) (Fig. 6e). At the same time, the lower-than-normal SLP is observed north-west of the studied area-above $-6 \mathrm{hPa}$ over the Fram Strait. The interpretation of the contoured composite anomalies is similar to the traditional weather anomaly maps, with clockwise (anticyclonic) flow around the positive centres and counter clockwise (cyclonic) flow around the negative centres (Birkeland and Mock 1996). Consequently, the circulation during the extremely cloudy days in winter is characterized by a strong southerly and south-westerly flow component, in contrast to the average winter circulation over the North Atlantic. This entails positive anomalies of T850 over the Svalbard Archipelago $\left(>3{ }^{\circ} \mathrm{C}\right)$ and the entire north Atlantic (Fig. 6g).

The mean SLP over the Arctic in summer distinctly differs from the winter one, i.e. it is much less diversified and the gradient of the pressure field is very small (about $4 \mathrm{hPa}$ ) (Fig. 7a). Values of mean summer SLP range from $1009 \mathrm{hPa}$ south-west to Iceland to $1013 \mathrm{hPa}$ over Greenland. It is a small spatial variability in comparison with the winter SLP spatial range (997 to $1021 \mathrm{hPa}$ ).

At a composite contour map of SLP constructed for the days with negative extremes of cloudiness (156 days with sunny weather), a distinct anticyclone spreads over the archipelago and to its west (Fig. 7b). This anticyclone is the centre of the strongest positive SLP anomalies, exceeding $6 \mathrm{hPa}$ over the northern Svalbard and the Fram Strait (Fig. 7d). Positive SLP anomalies take over most of the studied area, while weak negative SLP anomalies (up to $-3 \mathrm{hPa}$ ) are detected over northern Europe. Both the composite and anomaly maps of SLP indicate a north-easterly flow over the North Atlantic, while most of the Spitsbergen Island remains under the influence of a high pressure system. For the summer season, absolute values of SLP anomalies higher than $1.0 \mathrm{hPa}$ express statistically significant $(p=0.05)$ difference between composites and means, according to the $t$ test. Despite the northeasterly flow, sunny weather in Spitsbergen is associated with positive anomalies of T850 over the island and west to it (Fig. 7f). In summer, absolute values of T850 anomalies higher than $0.55{ }^{\circ} \mathrm{C}$ are statistically significant at $p=0.05$, according to the $t$ test.

In the contour map of SLP, constructed for the selected 453 days with extremely cloudy weather in summer, the pressure gradient is small. A weak anticyclone spreads over the Barents Sea, the Novaya Zemlya archipelago and the Kara Sea, while slightly lower-than-normal pressure is observed over Greenland (Fig. 7c, e). Such a pressure pattern enhances southerly and south-westerly flow of air masses, bringing humid air (warmer-than-normal by approximately $1^{\circ}$ ) over the Spitsbergen Island (Fig. 7g).

\section{Conclusions and discussion}

The annual cycle of cloudiness at Svalbard Lufthavn is typical of the Arctic, with its minimum in the winter and the maximum in the late summer and early autumn (Schweiger and 


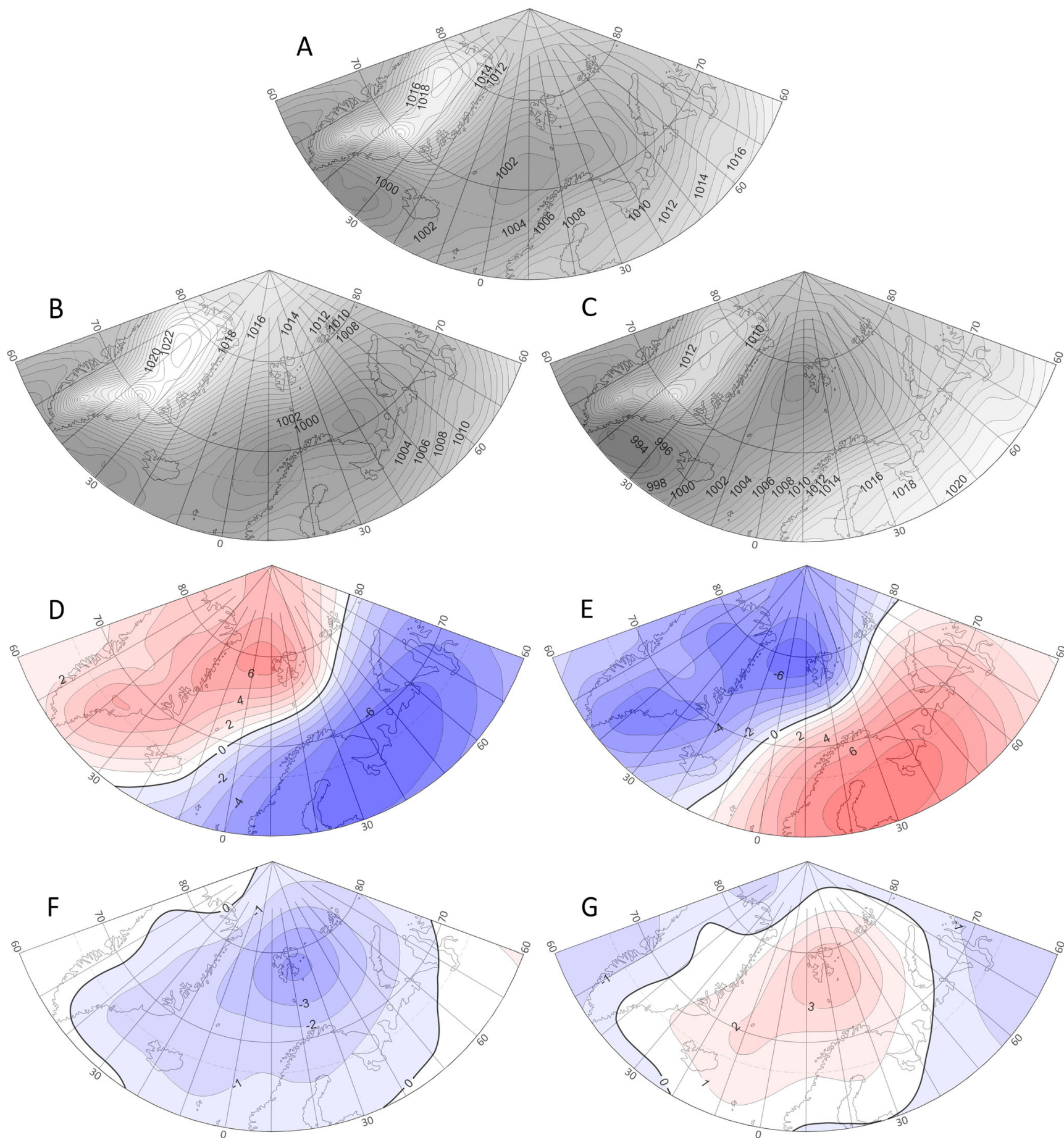

Fig. 6 Mean SLP in winter in hectopascal (a). Composite maps of SLP in negative (b) and positive (c) extremes of cloudiness in hectopascal. Anomalies of SLP in negative (d) and positive (e) extremes of cloudiness

Key 1992; Przybylak 1999; Shupe et al. 2011; Barton et al. 2012). The summer maximum corresponds to higher temperature and, accordingly, higher saturation and, presumably, higher evaporation from ice-free and relatively warm ocean waters. The 30-year distribution of mean annual cloudiness at Svalbard Lufthavn does not reveal any significant trend. Only the winter values of mean cloudiness show a statistically in hectopascal. Anomalies of T850 in negative (f) and positive (g) extremes of cloudiness in winter in Kelvin

significant positive trend. Similar results obtained for Spitsbergen and the entire Atlantic region of the Arctic were cited by Przybylak (1999). Also, Eastman and Warren (2010) found increasing trend over the Arctic Ocean in all seasons. Different results, i.e. decreasing trends of cloudiness for the winter season, were derived from the satellite datasets (Comiso 2003; Wang and Key 2003; Schweiger 2004; 


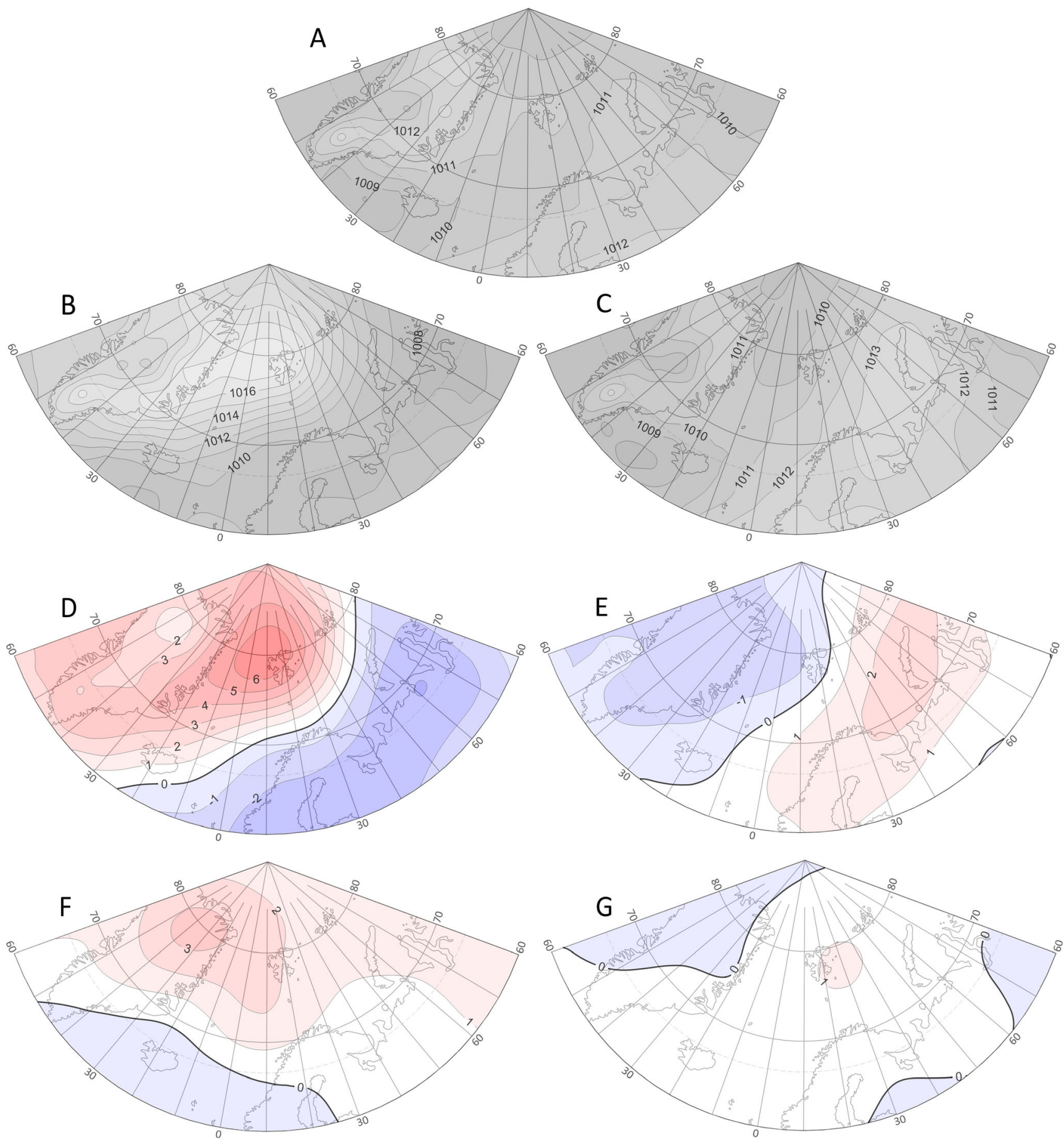

Fig. 7 Mean SLP in summer in hectopascal (a). Composite maps of SLP in negative (b) and positive (c) extremes of cloudiness in hectopascal. Anomalies of SLP in negative (d) and positive (e) extremes of cloudiness

Chernoulsky and Mokhov 2012). According to Przybylak (1999), we do not know which climatology (station-based or satellite) is correct. Uncertainties in the various data sets seem to be too large to detect the small trends reliably.

Cloudiness is considered to be an important factor which determines the radiation budget thus influencing the surface in hectopascal. Anomalies of T850 in negative (f) and positive (g) extremes of cloudiness in winter in Kelvin

temperature. In the Arctic, clouds have a warming effect in general, apart from a short midsummer period, when they may enhance surface cooling (Intrieri et al. 2002; Curry et al. 1996; Wang and Key 2003; Shupe and Intrieri 2004; Vavrus 2004; Vavrus et al. 2011). During the short Arctic summer, clouds tend to reduce the daily maximum air temperature, while 
during the long Arctic winter, they increase the air temperature by reducing the earth surface radiation (Przybylak 1999).

Most of the models concerning future cloudiness in the Arctic emphasize the role of sea ice reduction and increase of sea surface temperature which enhance evaporation (Schweiger et al. 2008; Kay and Gettelman 2009; Eastman and Warren 2010; Palm et al. 2009). Vavrus et al. (2009) proved that the Arctic cloud changes according to the GCMs are not significantly correlated with changes in sea level pressure, which means that cloudiness is not significantly influenced by circulation patterns. However, Vavrus et al. (2011) considered dynamical influences, namely meridional transport of moisture into the Arctic, as being a key factor in explaining the response of middle and high clouds.

According to our study, the atmospheric circulation is relevant for cloudiness over the Spitsbergen Island. It has been proven that intensive cyclogenesis, taking place over the north Atlantic expressed by lower-than-normal SLP particularly over the Fram Strait and over the east coast of Greenland, enhances the meridional air transport from the southern sector which conveys positive anomalies of cloudiness, namely a very cloudy weather. The Fram Strait has been recognized by Rogers et al. (2005) as one of the three 'centres of action' exhibiting intensive cyclogenesis in winter and as a pathway of cyclonic activity trending towards the high Arctic. Negative anomalies of cloudiness understood as clear sky conditions over Svalbard Lufthavn occur in the winter when the north Atlantic cyclone path is shifted to the south and goes along the northern Norwegian shore towards the south Barents Sea. This area is identified by Serreze and Barry (1988) and Serreze et al. (1993) as an alternative 'centre of action' exhibiting intensive cyclogenesis, and as a winter cyclone path.

In summer, the influence of pressure patterns on cloudiness is weaker than in winter and quite different circulation patterns induce negative anomalies of cloudiness. In the warm season, sunny weather occurs when a distinct anticyclone spreads over the Svalbard Archipelago and to its west, over the Fram Strait and the northern outskirts of the Greenland Sea. Extremely cloudy weather occurs in summer when a weak anticyclone spreads over the Barents Sea, the Novaya Zemlya archipelago and the Kara Sea, while slightly lower-than-normal pressure is observed over Greenland. Such a pressure pattern enhances southerly and south-westerly flow of air masses, bringing humid air.

The results obtained in this study demonstrate that cloudiness in the Atlantic region of the Arctic is strongly controlled by the air circulation arising from pressure patterns. In winter, different types and scenarios of cyclonic activity bring about the extremes of cloudiness, while in summer, the position of anticyclones is a driving factor for the occurrence of sunny or extremely cloudy weather.
Extreme meteorological phenomena are an important object of climatological studies, particularly in the age of dynamic climate changes (IPCC 2007). Cloudiness, although considered to be an important factor determining the rate of warming in the Arctic, is difficult for modelling. Studies concerning the relationship between cloudiness and air circulation may help in understanding the process of the meridional transport of moisture into the Arctic.

Acknowledgments This work was partly supported by the Polish National Science Centre under grant number 2011/01/B/ST10/01923.

Open Access This article is distributed under the terms of the Creative Commons Attribution License which permits any use, distribution, and reproduction in any medium, provided the original author(s) and the source are credited.

\section{References}

Andrews T, Gregory JM, Forster PM, Webb MJ (2012) Cloud adjustment and its role in $\mathrm{CO} 2$ radiative forcing and climate sensitivity: a review. Surv Geophys 33:619-635

Andrews T, Ringer MA (2014) Cloud feedbacks, rapid adjustments, and the forcing-response relationship in a transient $\mathrm{CO} 2$ reversibility scenario. J Clim 27:1799-1818

Barton NP, Klein SA, Boyle JS, Zhang YY (2012) Arctic synoptic regimes: comparing domain wide Arctic cloud observations with CAM4 and CAM5 during similar dynamics. J Geophys Res 117, D15205

Bednorz E (2011) Occurrence of winter air temperature extremes in Central Spitsbergen. Theor Appl Climatol 106(3-4):547-556

Bednorz E, Kolendowicz L (2013) Summer mean daily air temperature extremes in Central Spitsbergen. Theor Appl Climatol 113:471-479

Birkeland KW, Mock CJ (1996) Atmospheric circulation patterns associated with heavy snowfall events, Bridger Bowl, Montana, U.S.A. Mt Res Dev 16:281-286

Chernoulsky A, Mokhov II (2012) Climatology of total cloudiness in the Arctic. An intercomparison of observations and reanalyses advances in meteorology v. 2012, Article ID 542093, 15 pp

Comiso JC (2003) Warming trends in the Arctic from clear-sky satellite observations. J Clim 16(21):3498-3510

Crane KG, Barry RG (1984) The influence of clouds on climate with a focus on high latitude interactions. J Clim 4:71-93

Curry JA, Schramm JL, Rossow WB, Randall D (1996) Overview of arctic cloud and radiation characteristics. J Clim 9(8):1731-1764

Dayan U, Tubia A, Levy I (2012) On the importance of synoptic classification methods with respect to environmental phenomena. Int $\mathrm{J}$ Climatol 32:681-694

Eastman R, Warren SG (2010) Interannual variations of Arctic cloud types in relation to sea ice. J Clim 23:4216-4232

Førland EJ, Hanssen-Bauer I, Nordli PØ (1997) Climate statistics and long term series of temperature and precipitation at Svalbard and Jan Mayen. DNMI - Rapport 21/97. Norwegian Meteorological Institute, Oslo

Hanssen-Bauer I, Forland EJ (1998) Long-term trends in precipitation and temperature in the Norwegian Arctic: can there be explained by changes in atmospheric circulation patterns? Clim Res 10:143-153 
Haugan PM (1999) Structure and heat content of the West Spitsbergen Current. Polar Res 18:183-189

Intrieri JM, Fairall CW, Shupe MD, Persson POG, Andreas EL, Guest PS, Moritz RM (2002) An annual cycle of Arctic surface cloud forcing at SHEBA. J Geophys Res-Oceans 107(C10)

IPCC (2007) Climate change 2007, The physical science basis, Summary for Policymakers: $18 \mathrm{pp}$

Kalnay E, Kanamitsu M, Kistler R, Colins W, Deaven D, Gandin L, Iredell M, Saha S, White G, Woollen J, Zhu Y, Leetmaa A, Reynolds R, Chelliah M, Ebisuzaki W, Higgins W, Janowiak J, Mo KC, Ropolewski C, Wang J, Jenne R, Joseph D (1996) The MNC/NCAR 40-Year Reanalysis Project. Bull Am Meteorol Soc 77:437-471

Kay JE, Gettelman A (2009) Cloud influence on and response to seasonal Arctic sea ice loss. J Geophys Res 114:D18

Kotarba A, Widawski A (2008) Satelitarna charakterystyka zachmurzenia ogólnego nad Svalbardem w roku (2007) w powiązaniu z cyrkulacją atmosfery (Satellite characteristic of cloudiness over Svalbard in relations to atmospheric circulation). Probl Klimatol Polarnej 18: $127-140$ (in Polish)

Maciejowski W, Michniewski A (2007) Variations in weather on the East and West coasts of South Spitsbergen, Svalbard. Pol Polar Res 28: 123-136

Markin WA (1975) Klimat obłasti sowriemiennogo oliedienienija. Oliedienienije Szpicbergena (Svalbarda). Nauka, Moskwa (in Russian)

Marsz A, Styszyńska A (2007) Klimat rejonu Polskiej Stacji Polarnej w Hornsundzie - stan, zmiany i przyczyny (Climate of Polish polar station in Hornsund - the state, changes and reasons). Wydawnictwo Akademii Morskiej w Gdyni, Gdynia (in Polish)

McCabe GJ, Clark MP, Serreze MC (2001) Trends in Northern Hemisphere Surface Cyclone Frequency and Intensity. J Clim 14: 2763-2768

Niedźwiedź T (2003) Współczesna zmienność cyrkulacji atmosfery, temperatury powietrza i opadów atmosferycznych na Spitsbergenie (Contemporary variability of atmospheric circulation, temperature and precipitation in Spitsbergen). Probl Klimatol Polarnej 13:79-92 (in Polish)

Niedźwiedź T (2006) Główne cechy cyrkulacji nad Spitsbergenem (XII.1950 - IX.2006) (The main features of atmospheric circulation over Spitsbergen. December 1950 - September 2006). Probl Klimatol Polarnej 16:91-105 (in Polish)

Niedźwiedź T (2001) Zmienność cyrkulacji atmosfery nad Spitsbergenem w drugiej połowie XX wieku (Variability of atmospheric circulation over Spitsbergen in the second half of $\mathrm{XX}^{\text {th }}$ century). Probl Klimatol Polarnej 11:7-26 (in Polish)

Niedźwiedź T (2013) Calendar of circulation types for Spitsbergen.dataset of Department of Climatology, University of Silesia, Sosnowiec, available at: http://klimat.wnoz.us.edu.pl/\#!/podstrony/ kalendarztn

Nordli PØ (1990) Temperature and precipitation series at Norwegian Arctic meteorological stations. DNMI KLIMA, Rapport 40/90:1-14

Palm SP, Marshak A, Yang Y, Spinhirne J, Markus T (2009) The influence of Arctic sea ice extent on polar cloud fraction and vertical structure and implications for regional climate. Proceedings of the 10th conference on polar meteorology and oceanography. American Meteorological Society, Madison, WI

Piechura J, Beszczyńska-Moller A, Osiński R (2001) Volume, heat and salt transport by the West Spitsbergen Current. Pol Polar Res 20: 233-240

Przybylak R (1999) Influence of cloudiness on extreme air temperatures and diurnal temperature range in the Arctic in 1951-1990. Pol Polar Res 20:149-173
Ramanathan V, Cess RD, Harrison EF, Minnis P, Barkstrom BR (1989) Cloud radiative forcing and climate: results from the earth radiation budget experiment. Science 243(4887):57-63

Rogers JC, Yang L, Li L (2005) The role of Fram Strait winter cyclones on sea ice flux and on Spitsbergen air temperatures. Geophys Res Lett 32, L06709

Schweiger A (2004) Changes in seasonal cloud cover over the Arctic seas from satellite and surface observations. Geophys Res Lett 31, L12207

Schweiger AJ, Key JR (1992) Arctic cloudiness: comparison of ISCCPC2 and NIMBUS-7 satellite-derived cloud products with a surfacebased climatology. J Clim 5:1514-1527

Serreze MC, Box RG, Barry RG, Walsh JE (1993) Characteristics of arctic synoptic activity. Meteorol Atmos Phys 51(3):147-164

Schweiger AJ, Zhang W, Lindsay JR, Steele M (2008) Did unusually sunny skies help drive the record sea ice minimum of 2007 ? Geophys Res Lett 35, L10503

Schweiger AJ, Lindsay RW, Key JR, Francis JA (1999) Arctic clouds in multiyear satellite data sets. Geophys Res Lett 26:1845-1848

Serreze MC, Barry RG (1988) Synoptic activity in the Arctic basin, 1979-85. J Clim 1:1276-1295

Serreze MC, Walsh JE, Chapin III FS, Osterkamp T, Dyurgerov M, Romanovsky V, Oechel WC, Morison J, Zang T, Barry RG (2000) Observational evidence of recent change in the northern highlatitude environment. Clim Change 46:159-207

Shupe MD, Intrieri JM (2004) Cloud radiative forcing of the Arctic surface: the influence of cloud properties, surface albedo, and solar zenith angle. J Clim 17:616-628

Shupe MD, Von Walden P, Eloranta E, Uttal T, Campbell JR, Starkweather SM, Shiobara M (2011) Clouds at arctic atmospheric observatories. Part I: occurrence and macrophysical properties. J Appl Meteorol Climatol 50:626-644

Steffensen EL (1982) The climate at Norwegian Arctic stations. Det Norske Meteorologiske Institutt, Klima 5, Oslo

Stephens GL (2005) Cloud feedbacks in the climate system: a critical review. J Clim 18:237-273

Vavrus S, Waliser D, Schweiger A, Francis J (2009) Simulations of 20th and 21 st century Arctic clouds in the global climate models assessed in the IPCC AR4. Clim Dyn 33:1099-1115

Vavrus SJ, Bhatt US, Alexeev VA (2011) Factors influencing simulated changes in future arctic cloudiness. J Clim 24:4817-4830

Vavrus S (2004) The impact of cloud feedbacks on arctic climate under greenhouse forcing. J Clim 17(3):603-615

Walsh JE, Chapman WL (1998) Arctic cloud-radiation-temperature associations in observational data and atmospheric reanalyses. $\mathrm{J}$ Clim 11(11):3030-3045

Wang X, Key JR (2003) Recent trends in Arctic surface, cloud, and radiation properties from space. Science 299:1725-1728

Wielbińska D, Skrzypczak E (1988) Mean air temperature at definite wind directions in Hornsund, Spitsbergen. Pol Polar Res 9:105-119

Wilks DS (1995) Statistical methods in the atmospheric sciences, Academic Press, 467 p

Yarnal B (1993) Synoptic climatology in environmental analysis. Belhaven Press, London

Yarnal B, Comrie AC, Frakes B, Brown DP (2001) Developments and prospects in synoptic climatology. Int J Climatol 21:1923-1950

Zhang X, Walsh JE, Zhang J, Bhatt US, Ikeda M (2004) Climatology and inter-annual variability of Arctic cyclone activity: 1948-2002. J Clim 17:2300-2317

Żmudzka E (2007) Zmienność zachmurzenia nad Polską i jej uwarunkowania cyrkulacyjne (1951-2000). Wydawnictwa Uniwersytetu Warszawskiego, Warszawa (in Polish) 